to the necessity for anticonvulsant treatment.

It may be concluded from these studies that continuous prophylactic treatment with oral phenobarbitone at these dose levels, as suggested some years ago by Hammill and Carter, ${ }^{6}$ is an effective method of treatment which should therefore be given to all children with febrile seizures after their first episode. It should be continued for at least two years or until the age of 5 years, and it may be considered worthwhile during this time to make occasional estimations of the blood phenobarbitone concentration. That an effective continuous treatment regimen is worthwhile is supported by the occasional occurrence of irreversible brain damage sustained during a febrile seizure..$^{514}$ In addition febrile convulsions have been incriminated in the development of subsequent temporal lobe epilepsy. ${ }^{16}$ It is therefore possible that effective prevention and treatment of febrile seizures could lead to a decrease in the incidence of epilepsy in adult life.

Some of your readers may not agree with the view that continuous anticonvulsant medication is of value in the treatment of patients with febrile convulsions, but at least we feel that they should be aware of the great volume of work continuing on this subject, both in this country and abroad.We are, etc.,

\section{F. Scott}

The London Hospital,

Michael SWash

\section{London E.}

Briti:h Medical fournal, 1972, 1, 608.

Lewis, B. W., British Medical fourna!, 1972, 2 ,

Livingston, S., The Diagnosis and Treatment of Char es C. Thomas, 1954 .

4 Lennox-Buchthal, M., Epileps:a, 1971, 12, 147

Millichap, J. G., Febrile Convulsions. New York, MacMillan, 1968

Hammill, J. F.; and Carter, S., New England Fournal of Medicine, 1966, 274, 563.

Research, 1969, 3, 298.

Melch:er, J. C.' Buchthal F and Buchthal, M., Epilepsia. 1971, 12, 55.

Svensmark, O., and Buchthal, F., American Fournal of Diseases of Childhood, 1964, 108, 82. Buchanan, R. A., Kinkel, A. N. Goulet, J. R R
and Smith, T. C., Neurology, 1972, 22, 126.

and Smith, T. C., Neurology, 1972, 22, 126.
11 Faer, O., Kastrup, K. W., Lykkegaard-Nielsen,
E., Melchier, J. C., and Thorn, I., Ep:lepsia, E., Melchier,

12 Frantzen, E., Lennox-Buchthal, M., Nygiard, A., 13 and Stene, J., Neurology, 1970, 20 , 909 .

J. L. New England fournal of Medicine, 1972,

14 Fowler, M. Mrchives of Disease in Childhood, 1957, 32. 37.

Taylor, D. C., and Bowler, B. D., Lancet, 1971, 6 Ounsted,

et. D. Gairdner and D. Hull. London, Churchill, 1971 .

\section{Subclinical Brucella Infection in Man}

SIR,-Drs. R. J. Henderson and D. M. Hill (15 July, p. 154) draw attention to the booster effect on brucella antibodies of reexposure to Brucella abortus infection.

Serological follow up of patients occupationally at risk in West Dorset shows that titres may not always remain high if the interval between exposures is a year or more. Booster effects producing a fourfold or greater rise in titre (direct saline agglutination) are common in those previously exposed and provide a trap for the unwary serologist. For example, a dairy farmer who had $B$. abortus infection with positive blood culture in November 1969 showed serological evidence of cure and disappearance of his symptoms, direct saline agglutination titres falling from 1,280 to 320 during the following six months, but follow up revealed that in April 1971 the titre had risen to over 2,580 , the man being quite symptom free. If he had chanced to have an illness sug gesting brucella in April 1971 an eight-fold rise in titre might have been interpreted as evidence of his symptoms being due to brucella relapse or active reinfection. effect of symptomless reinfection may be accompanied by a rising complement fixation titre, as the following example shows. The patient is a dairyman who had an acute llness with positive blood culture in July 1971.

\begin{tabular}{c|c|c}
\hline Date & $\begin{array}{c}\text { B. abortus } \\
\text { Saline Agglu- } \\
\text { lination }\end{array}$ & Complement Fixation \\
July 1971 & 1,280 & 40 \\
Aug. 1971 & 640 & 40 \\
Sept 1971 & 320 & less than 5 \\
Jan. 1972 & Over 2,560 & \\
\hline
\end{tabular}

In this instance the 2-mercaptoethanol titre was 640 in January 1972 suggesting that IgM antibody was present, yet this patien had no symptoms after the second week of his six weeks of treatment in the summer of 1971. He was well in January 1972 at the time of re-exposure.-I am, etc.

GEORGE TEE

Public Health Laboratory
Dorchester, Dorset

\section{Faecal Flora after Prolonged Co-trimoxazole} Treatment

SIR,-We were interested to read that Professor W. Brumfitt and Miss Rita Pursell (17 June, p. 673) did not find trimethoprimresistant organisms in the faeces of patients treated with comparatively low doses (100 mg daily) of trimethoprim alone for periods of up to a year. We should like to report the changes in the faecal flora of a patient who received unusually high doses of $\mathrm{co}$ trimoxazole for nearly a year.

As successful treatment of Pseudomonas cepacia endocarditis of a prosthetic mitral valve a 48-year-old woman received $0.64 \mathrm{~g}$ of trimethoprim and $3.20 \mathrm{~g}$ of sulphamethoxazole (8 tablets of Septrin) daily for seven weeks in hospital, and then $0.48 \mathrm{~g}$ of trimethoprim and $2.40 \mathrm{~g}$ of sulphamethoxazole (6 tablets of Septrin) daily for ten months at home. Kanamycin $1 \mathrm{~g}$ daily was also given for the first three weeks of treatment. She suffered no adverse effects and did not complain of any gastrointestinal disturbance.

We were interested to discover whether at the end of this long course of treatmen her faecal flora included coliforms and other Gram-negative bacilli resistant to cotrimoxazole. A faecal specimen collected two days after she stopped taking the drug could not be made to yield any aerobic Gramnegative bacilli at all, even after heavy plating on selective media, and the organisms isolated were all of species generally resistant to co-trimoxazole. (We could not
It is important to stress that the booster

detect in the faeces residual antibacterial activity such as might have caused inhibition of sensitive strains in our cultures.) Aerobic Gram-negative bacilli were similarly undetectable in a specimen collected 10 days after the end of treatment, but after 5 weeks lactose-fermenting coliforms had reappeared and these isolates were all sensitive to co-trimoxazole and to trimethoprim alone. Approximate viable counts, per gramme of faeces, of the principal organisms found in the three specimens are given below; Clostridia and Lactobacilli were also present in all three.

\begin{tabular}{|c|c|c|c|c|}
\hline \multirow[b]{2}{*}{ Organisms } & & \multicolumn{3}{|c|}{ Time after Stopping Drug } \\
\hline & & 2 days & 10 days & 5 weeks \\
\hline $\begin{array}{l}\text { Lactose-fermenting } \\
\text { coliforms } \\
\text { Bicteroides sp .. } \\
\text { Faecal streptococci } \\
\text { Candida sp. .. }\end{array}$ & $\begin{array}{l}\because \\
\because \\
\therefore\end{array}$ & $\begin{array}{c}\text { none } \\
\text { detected } \\
10^{9} \\
10^{5} \\
10^{4}\end{array}$ & $\begin{array}{c}\text { none } \\
\text { detected } \\
10^{\circ} \\
10^{6} \\
10^{4}\end{array}$ & $\begin{array}{l}10^{\circ} \\
10^{\circ} \\
10^{6} \\
10^{2}\end{array}$ \\
\hline
\end{tabular}

It has been suggested ${ }^{1}$ that in low dosage trimethoprim is almost completely absorbed and so does not upset the flora of the lower gut. The high dose given to this patient, however, appears to have eradicated or strikingly reduced her normal coliform flora without bowel upset and without colonization by resistant strains. Administration of sulphonamides alone is rapidly followed by colonization of the gut by sulphonamide-resistant coliforms, ${ }^{2}$ but it was to be expected that this would be prevented or delayed by the addition of trimethoprim. It is probable that in the domestic environment Gram-negative bacilli resistant to the combination are rare, and that even in hospitals resistant coliforms are infrequent at present, ${ }^{3}$ although resistant pseudomonads are common and might be expected to colonize the gut of patients on treatment.-We are, etc.,

D. C. E. SPELLER D. M. BRUTEN

Department of Bacteriology,

Royal Infirmary

Bristol

1 Q'Grady, F., et al., Postgraduate Medical fournal, 1969, 45, Supplement, p. 61

British Kedical fournal, 1970 , and Winberg, J. British Medical fournal, 1970,3 , 305. and Lewis, E. L., Lancet, 1972, 1, 409.

\section{Rickets in Glasgow Pakistanis}

SIR,-In the interesting article by Dr. J. A. Ford and others (17 June, p. 677) it seems that the authors noted but placed little weight on the possible role of skin pigmentation in the increased incidence of rickets and osteomalacia in the Pakistanis living in Glasgow. In doing so they were perhaps misled by their assumption that skins of Pakistanis living in Glasgow "are no darker than those of many southern Europeans."

In the Table are shown the percentage reflectance values (mean and standard deviations) for a sample of southern Europeans (Italians) ${ }^{1}$ and a sample of Punjabis in Britain (Sikhs, personal observation, 1972) The Punjabi group is conspicuously darker than the Italians. This is especially clear at

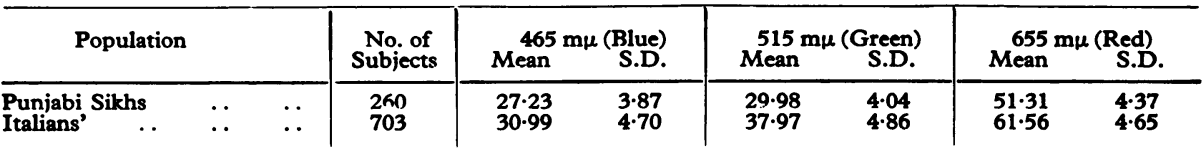

